\title{
Isoconversional kinetic analysis applied to five phosphonium cation-based ionic liquids
}

\author{
D. Blanco ${ }^{\mathrm{a}^{*}}$, M. Bartolomé ${ }^{\mathrm{b}}$, B. Ramajo ${ }^{\mathrm{c}}$, J.L. Viesca ${ }^{\mathrm{a}, \mathrm{d}}$ \\ R. González ${ }^{\mathrm{b}, \mathrm{d}}$, A. Hernández Battez ${ }^{\mathrm{a}, \mathrm{d}}$ \\ ${ }^{a}$ Department of Construction and Manufacturing Engineering, University of Oviedo, Asturias, Spain \\ ${ }^{\mathrm{b}}$ Department of Marine Science and Technology, University of Oviedo, Asturias, Spain \\ ${ }^{\mathrm{c}}$ Department of Physical and Analytical Chemistry, University of Oviedo, Asturias, Spain \\ ${ }^{\mathrm{d}}$ Department of Design and Engineering, Bournemouth University, Poole, BH12 5BB, UK \\ ${ }^{(*)}$ Email: blancoadavid@uniovi.es
}

\begin{abstract}
Thermal degradation of five phosphonium cation-based ionic liquids ([ $\left.\mathrm{P}_{66614}\right][\mathrm{BEHP}],\left[\mathrm{P}_{66614}\right]\left[\left(\mathrm{iC}_{8}\right)_{2} \mathrm{PO}_{2}\right]$, $\left[\mathrm{P}_{66614}\right]\left[\mathrm{NTf}_{2}\right],\left[\mathrm{P}_{44414}\right][\mathrm{DBS}]$ and $\left.\left[\mathrm{P}_{4442}\right][\mathrm{DEP}]\right)$ was studied using dynamic methodology (25 to $600{ }^{\circ} \mathrm{C}$ at 5, 10 and $20^{\circ} \mathrm{C} / \mathrm{min}$ ) in both inert (nitrogen) and reactive (oxygen) atmospheres. In addition, isothermal experiments (90 min at 200, 225 and $250{ }^{\circ} \mathrm{C}$ ) were carried out with $\left[\mathrm{P}_{66614}\right]\left[\left(\mathrm{iC}_{8}\right)_{2} \mathrm{PO}_{2}\right]$. Results indicate that thermal stability is clearly dominated by the coordination ability of the anion, with $\left[\mathrm{P}_{66614}\right]\left[\mathrm{NTf}_{2}\right]$ outperforming the other ones in both pyrolytic and oxidising conditions. Although the thermal degradation mechanism is affected by atmospheric conditions, the degradation trend remains practically constant. As the dynamic methodology usually overestimates the long-term thermal stability, an isoconversional methodology is better for predicting the long-term thermal stability of these ionic liquids in order to be used as base oil or additive in lubricants formulation. Finally, the model-free methodology can predict at lower costs the ILs performance in isothermal conditions.
\end{abstract}

\section{Highlights}

- Weakly coordinating anions provoke good thermal stability of ILs.

- $\quad\left[\mathrm{P}_{66614}\right]\left[\mathrm{NTf}_{2}\right]$ and $\left[\mathrm{P}_{44414}\right][\mathrm{DBS}]$ are the most thermally stable ILs in this study.

- Isoconversional methods are better than dynamic ones for long-term thermal studies.

- Activation energy behavior at low conversions is related to a single reaction.

- Model-free methodology can predict the ILs performance in isothermal conditions.

Keywords: ionic liquids; thermogravimetric analysis; isoconversional method; model-free kinetics 


\section{Introduction}

Ionic liquids (ILs) are salts typically formed by the combination of large organic cations (commonly containing large alkyl chains) and a variety of anions (either inorganic or organic). In the last 15 years, the use of ILs has increased considerably due to their interesting chemical and physical properties, such as negligible vapour pressure, high thermal stability, low melting point, high solvating capacity, high thermal conductivity and wide electrochemical window [1-6]. These properties mean that ILs are excellent candidates for various applications, including their use as environmentally friendly solvents for replacing traditional volatile organic ones $[7,8]$. Currently, growing interest is focused on the use of ILs for high temperature applications, such as thermal fluids and electrolytes for solar cells and fuel cells $[9,10]$. Significant research has been focused on the thermophysical properties of imidazolium-based ILs [11,12], but there are only a few studies focused on a novel class of ILs based on phosphorous quaternary cations $[13,14]$. The phosphorus atom allows for bonding with different substituents, giving a great number of different structures and physicochemical properties [15,16].

One of the most important characteristics of ILs is their thermal stability. An appropriate estimation of this property is a key factor in many engineering applications, including lubrication [17]. Despite the fact that a significant number of works have been focused on the study of thermal degradation of ILs [18-25], only a few of them have used phosphonium based ILs $[13,15,26]$. In addition, thermal stability is often misleadingly reported to extend up to temperatures of more than $400^{\circ} \mathrm{C}$. This issue occurs if high heating rates $(>10 \mathrm{~K} / \mathrm{min})$ are used in the temperature ramped thermogravimetric analysis (TGA) studies, overestimating the thermal stability of the analysed samples [22-25]. Due to the fact that most applications require long-term thermal stability, more reliable data is needed in this field. A full evaluation of the long-term thermal stabilities and thermal decomposition is necessary to identify global kinetic models. Nowadays, the knowledge of the kinetic parameters, such as reaction rate and activation energy, is one of the key factors for determining thermal stability. Some research has been focused on the determination of activation energies and kinetic models, describing the thermal degradation of some ILs. Most of these studies performed kinetic analyses based on isothermal experiments. In these cases, some isothermal experiments were measured at low temperatures (below onset temperature) and kinetic parameters were determined assuming zero-order processes [10,27]. Therefore, a prediction of the longterm stability of ILs based on the modelling of non-isothermal TG measurements enables to reduce significantly the time required to carry out the experiment, resulting in a considerable cost reduction [23]. 
Lubricant oils used in cooling engine parts are exposed to high and long-term thermal stress, which leads to thermal degradation (evaporation of volatiles) and polymerisation, forming a heavier fraction [28]. Volatility is the main parameter linked to oil consumption and, besides the Noack volatility test, the volatility of oils and additives have been measured using TGA [17]. A lot of researches have been published concerning the use of ionic liquids as lubricants since 2001 [29], proving their remarkable potential for this purpose [4,6,30-32]. At the beginning, imidazolium-based ionic liquids with $\left[\mathrm{PF}_{6}\right]$ and $\left[\mathrm{BF}_{4}\right]$ anions were widely used [33-35]. Despite their good tribological behaviour, the hydrolysis products of those anions are highly corrosive [36]. This fact provoked the introduction of new and more stable ILs based on [FAP] and $\left[\mathrm{NTf}_{2}\right]$ anions [37-53], which present enhanced tribological properties due to the formation of fluoride tribofilms, especially at high loads [54]. Recently, phosphonium cation-based ILs have been introduced in this field because of their growing commercial availability and good tribological performance [26,55-62]. Finally, taking into account the importance of thermal stability in the lifetime of lubricants and additives, the determination of thermal models has become an interesting research topic from scientific and technical points of view.

In this work, an alternative approach using an isoconversional (model-free) methodology is proposed to derive the long-term stabilities of five phosphonium cation-based ILs: trihexyltetradecylphosphonium bis(2-ethylhexyl)phosphate ([ $\left.\left.\mathrm{P}_{66614}\right][\mathrm{BEHP}]\right)$, trihexyltetradecylphosphonium bis(2,4,4-trimethylpentyl) phosphinate ([ $\left.\left.\mathrm{P}_{66614}\right]\left[\left(\mathrm{iC}_{8}\right)_{2} \mathrm{PO}_{2}\right]\right)$, trihexyltetradecylphosphonium bis(trifluoromethylsulfonyl) imide

$\left(\left[\mathrm{P}_{66614}\right]\left[\mathrm{NTf}_{2}\right]\right), \quad$ tributyltetradecylphosphonium dodecylbenzenesulfonate $\left(\left[\mathrm{P}_{44414}\right][\mathrm{DBS}]\right)$ and tributylethylphosphonium diethylphosphate $\left(\left[\mathrm{P}_{4442}\right][\mathrm{DEP}]\right)$. Previous papers $[27,63]$ have determined that both model-free and isothermal model-fitting methodologies are in good agreement. Using isoconversional methods, kinetic parameters can be derived without any assumption of the mechanism. Furthermore, an isoconversional rate expression determined using non-isothermal (dynamic) data can predict isothermal reaction data.

\section{Experimental}

\subsection{Ionic liquids}

Chemical and structural descriptions of the five ILs used, ([ $\left.\mathrm{P}_{66614}\right]\left[\left(\mathrm{iC}_{8}\right)_{2} \mathrm{PO}_{2}\right], \quad\left[\mathrm{P}_{66614}\right][\mathrm{BEHP}]$, $\left[\mathrm{P}_{66614}\right]\left[\mathrm{NTf}_{2}\right],\left[\mathrm{P}_{44414}\right][\mathrm{DBS}]$ and $\left.\left[\mathrm{P}_{4442}\right][\mathrm{DEP}]\right)$, are shown in Table 1 . These liquids were provided by Ionic Liquid Technologies GmbH, chosen from an available family of ILs (phosphonium cation-based) 
that is currently gaining consideration because of their possible use in lubricant applications (as base fluid or additive).

Table 1. Chemical and structural descriptions of the ILs used in this work.

\begin{tabular}{|c|c|c|c|c|}
\hline IUPAC and short name & $\begin{array}{l}\text { Empirical } \\
\text { formula }\end{array}$ & $\begin{array}{c}\text { Purity } \\
\text { (\%) }\end{array}$ & $\begin{array}{l}\text { Molecular } \\
\text { weight }\end{array}$ & Chemical structure \\
\hline $\begin{array}{l}\text { Trihexyltetradecylphosphonium } \\
\text { bis(2,4,4-trimethylpentyl) } \\
\text { phosphinate }\end{array}$ & $\mathrm{C}_{48} \mathrm{H}_{102} \mathrm{O}_{2} \mathrm{P}_{2}$ & 95 & 773.27 & \\
\hline $\begin{array}{l}\text { Trihexyltetradecylphosphonium } \\
\text { bis(2-ethylhexyl)phosphate }\end{array}$ & $\mathrm{C}_{48} \mathrm{H}_{102} \mathrm{O}_{4} \mathrm{P}_{2}$ & 98 & 805.29 & \\
\hline $\begin{array}{l}\text { Trihexyltetradecylphosphonium } \\
\text { bis(trifluoromethylsulfonyl) } \\
\text { imide }\end{array}$ & $\mathrm{C}_{34} \mathrm{H}_{68} \mathrm{~F}_{6} \mathrm{NO}_{4} \mathrm{PS}_{2}$ & 98 & 764.01 & \\
\hline $\begin{array}{l}\text { Tributyltetradecylphosphonium } \\
\text { dodecylbenzenesulfonate }\end{array}$ & $\mathrm{C}_{44} \mathrm{H}_{85} \mathrm{O}_{3} \mathrm{PS}$ & 95 & 725.18 & \\
\hline $\begin{array}{l}\text { Tributylethylphosphonium } \\
\text { diethylphosphate }\end{array}$ & $\mathrm{C}_{18} \mathrm{H}_{42} \mathrm{O}_{4} \mathrm{P}_{2}$ & 95 & 384.47 & \\
\hline$\left[\mathrm{P}_{4442}\right][\mathrm{DEP}]$ & & & & \\
\hline
\end{tabular}

\subsection{Thermal analysis}

Thermal analysis was performed in a Mettler Toledo TGA/SDTA 851 thermogravimetric analyser, operating in dynamic and isothermal modes under dry nitrogen and oxygen atmospheres (50 mL/min). Ionic liquid samples (10-12 mg) used as supplied by Ionic Liquid Technologies GmbH were placed in an open aluminium crucible without any previous treatment. Dynamic experiments were performed at 
temperatures from 25 to $600{ }^{\circ} \mathrm{C}$ at three different heating rates (5, 10 and $20{ }^{\circ} \mathrm{C} / \mathrm{min}$ ). Isothermal experiments were conducted at three different fixed temperatures (200, 225 and $\left.250{ }^{\circ} \mathrm{C}\right)$ during 90 min tests. Results were analysed using Mettler-Toledo STARe version software. The onset temperature $\left(\mathrm{T}_{\text {onset }}\right)$ is the intersection of the baseline weight and the tangent of the weight versus temperature curve as decomposition occurs. In addition, other temperatures were determined at $10 \%$ of mass loss, total mass loss, as well as the minimum of differential thermogravimetric (DTG) peaks.

\subsection{Kinetic parameters and modelling}

The mass loss of an IL under a thermogravimetric experiment may be the result of combining evaporation and/or thermal decomposition kinetics $[23,64,65]$. The rate of evaporation can be defined using eq. (1), as the mass transfer of the IL into the gas stream flowing over the crucible that contains the sample.

$$
\frac{d m}{d t}=M_{I L} B A \frac{p_{\text {vap }}(T)}{R T}
$$

where $M_{I L}$ is the molar mass of the ionic liquid, $B$ is the mass transfer coefficient, $A$ is the surface area in contact with the gas phase and $p_{\text {vap }}$ the vapour pressure. In addition, the rate of heterogeneous thermal decomposition can be described by eq. (2):

$$
\frac{d \alpha}{d t}=k(T) f(\alpha)
$$

In eq. (2): $t$ is time, $k(T)$ is the temperature-dependent constant and $f(\alpha)$ is a function called the reaction model, which describes the dependence of the reaction rate on the extent of conversion, $\alpha$.

The rates of evaporation and decomposition increase almost exponentially with temperature, being the decomposition rate more sensitive than the evaporation rate. Thus, at both high heating rates and temperature ranges, thermal decomposition may control the overall mass loss (and vice versa) [64]. Assuming that heating rates used in the TGA experiments carried out in this study can be considered as "high" (>4 K/min), the kinetic process is mainly controlled by thermal decomposition within the whole range of conversion, and eq. (1) could be negligible. In a TGA experiment in which the mass variation versus temperature is obtained, the extent of reaction is calculated using the following equation:

$$
\alpha=\frac{m_{i}-m_{t}}{m_{i}-m_{f}}
$$

where $m_{\mathrm{i}}$ and $m_{\mathrm{f}}$ are the initial and final masses, respectively, and $m_{\mathrm{t}}$ is the mass at a specific time, $t$. 
There are several methods for analysing thermal decomposition kinetic data [66]. These methods may be classified according to the experimental conditions selected and the mathematical analysis performed. Experimentally, both isothermal and non-isothermal methods are employed. The mathematical approaches employed can be divided into model-fitting and isoconversional (model-free) methods.

In model fitting methodologies, the term $f(\alpha)$ is determined by adjusting a reaction model to experimental data. Subsequently, $k(T)$ can be evaluated by the form of $f(\alpha)$ chosen. This is a limitation because the calculated kinetic parameters are very dependent upon the chosen kinetic model [67]. For zero-order processes, the degradation rate can be represented in integrate form as:

$$
\alpha=k(T) \cdot t+C
$$

Thus, using isothermal scans, it is possible to obtain $k(T)$ from a linear fitting of $\alpha$ versus time, where $C$ is a constant. Then, when $k(T)$ is known, the Arrhenius equation can be applied:

$$
\begin{gathered}
k=A e^{-E / R T} \\
\ln k=\ln A-\frac{E}{R T}
\end{gathered}
$$

In Eqs. (5) and (6), $A$ is the pre-exponential factor, $E$ is the activation energy and $R$ is the gas constant. Therefore, a plot of $\ln k(T)$ versus $(1 / T)$ will allow us to obtain $E$ from the slope. The major problem of this isothermal methodology is that the sample requires some time to reach the experimental temperature. Model-free (isoconversional) methods allow estimation of the activation energy as a function of $\alpha$ without choosing the reaction model. The basic assumption of these methods is that the reaction rate for a constant extent of conversion depends only on temperature. Considering non-isothermal experiments that are performed at constant heating rate $(\beta)$, Eq. (2) can be written as follows:

$$
\frac{d \alpha}{d T}=\frac{A}{\beta} e^{-E / R T} f(\alpha)
$$

An integration function is shown below, where $g(\alpha)$ is the integrated kinetic function or integral reaction model.

$$
\int_{0}^{\alpha} \frac{d \alpha}{f(\alpha)}=g(\alpha)=\frac{A}{\beta} \int_{T_{0}}^{T} e^{-E / R T} d T
$$

The use of several heating rates enables the application of model-free (isoconversional) methods. These methods make the assumption that the parameters of the model are identical for measurements at all heating rates. It allows for a direct fit of the model to the experimental data without any transformation 
[10]. An additional advantage lies in the fact that there are no limitations with respect to the complexity of the model; consequently, it is reliable for solving applied kinetic problems [68-71].

The integral on the right side of Eq. (8) has no analytical solution and some approximation methodology is necessary. The Kissinger-Akahaira-Sunose (KAS) method [72] is based on the following equation:

$$
\ln \frac{\beta}{\mathrm{T}_{\alpha}^{2}}=\ln \left[\frac{\mathrm{RA}}{\mathrm{E}_{\alpha} \mathrm{g}(\alpha)}\right]-\frac{\mathrm{E}_{\alpha}}{\mathrm{R}} \frac{1}{\mathrm{~T}_{\alpha}}
$$

To apply the method, it is necessary to obtain at least three different heating rates $(\beta)$, with the respective conversion curves being subsequently evaluated from the measured TGA curves [73]. For each conversion $(\alpha), \ln \frac{\beta}{T_{\alpha}^{2}}$ plotted against $1 / T_{\alpha}$, gives a straight line with slope $-\mathrm{E} \alpha / \mathrm{R}$ and thus, the activation energy is obtained as a function of the conversion. The evaluation of E $\alpha$ dependence is enough to predict the isothermal kinetics from non-isothermal data, as in Eq. (7):

$$
t_{\alpha}=\frac{\int_{0}^{T_{\alpha}} e^{-E_{\alpha} / R T} d T}{\beta e^{-E_{\alpha} / R T_{0}}}
$$

The time $\left(t_{\alpha}\right)$, computed by Eq. (10), will be reached at an arbitrary temperature $\left(T_{0}\right)$ with a given conversion $(\alpha)$.

\section{Results and discussion}

\subsection{Thermal decomposition}

Fig. 1 shows the TG and DTG curves obtained under inert (nitrogen) atmosphere for the five samples, with a very large range of thermal stability under these pyrolytic conditions (absence of oxygen). Most of the samples have an onset decomposition temperature over $300{ }^{\circ} \mathrm{C}$, with a couple of $\mathrm{T}_{\text {onset }}$ values even higher than $400{ }^{\circ} \mathrm{C}$. By analysing the obtained data, the most stable IL is $\left[\mathrm{P}_{66614}\right]\left[\mathrm{NTf}_{2}\right]$. The stabilities decrease in the order of $\left[\mathrm{P}_{66614}\right]\left[\mathrm{NTf}_{2}\right]>\left[\mathrm{P}_{44414}\right][\mathrm{DBS}]>\left[\mathrm{P}_{66614}\right]\left[\left(\mathrm{iC}_{8}\right)_{2} \mathrm{PO}_{2}\right]>\left[\mathrm{P}_{4442}\right][\mathrm{DEP}]>$ $\left[\mathrm{P}_{66614}\right][\mathrm{BEHP}]$. As shown by the DTG curves (Figs. 1c and 1d), the $\left[\mathrm{P}_{66614}\right]\left[\mathrm{NTf}_{2}\right],\left[\mathrm{P}_{44414}\right][\mathrm{DBS}]$ and $\left[\mathrm{P}_{66614}\right]\left[\left(\mathrm{iC}_{8}\right)_{2} \mathrm{PO}_{2}\right]$ samples exhibited only one resolved peak centred at 456,453 and $376{ }^{\circ} \mathrm{C}$, respectively

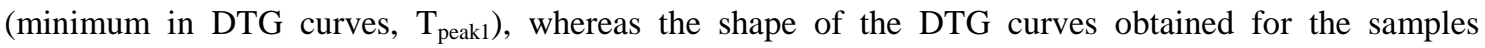
$\left[\mathrm{P}_{66614}\right][\mathrm{BEHP}]$ and $\left[\mathrm{P}_{4442}\right][\mathrm{DEP}]$ present a more complex mechanism. The latter ILs have, at this heating 
rate, two well-resolved peaks $\left(\mathrm{T}_{\text {peak1 }}\right.$ and $\left.\mathrm{T}_{\text {peak2 }}\right)$ at $331 / 467{ }^{\circ} \mathrm{C}\left(\left[\mathrm{P}_{66614}\right][\mathrm{BEHP}]\right)$ and $342 / 530{ }^{\circ} \mathrm{C}$ ([P $\left.\left.\mathrm{P}_{4442}\right][\mathrm{DEP}]\right)$. This behaviour is possibly related to the influence of a more reactive phosphate type anion [13], causing alkyl phosphates to pyrolyze readily at temperatures of $300{ }^{\circ} \mathrm{C}$ and above [74] and thus resulting in an extra peak. Early weight losses in all samples are probably related to the impurities (between 2-5\% in weight according to Table 1) present in the ionic liquids used in this study [15]; although they seem more pronounced with phosphate anion ILs (Fig. 1b), probably due to their water content. In view of these results, it can be concluded that anions play an important role in the mechanism of thermal decomposition, because of the similarity of all the cations used in this study. A previous research based on the thermal decomposition of amino- and hydroxyl-functionalised ILs composed of different cations showed that the stability of ILs is generally controlled by the anion [75].
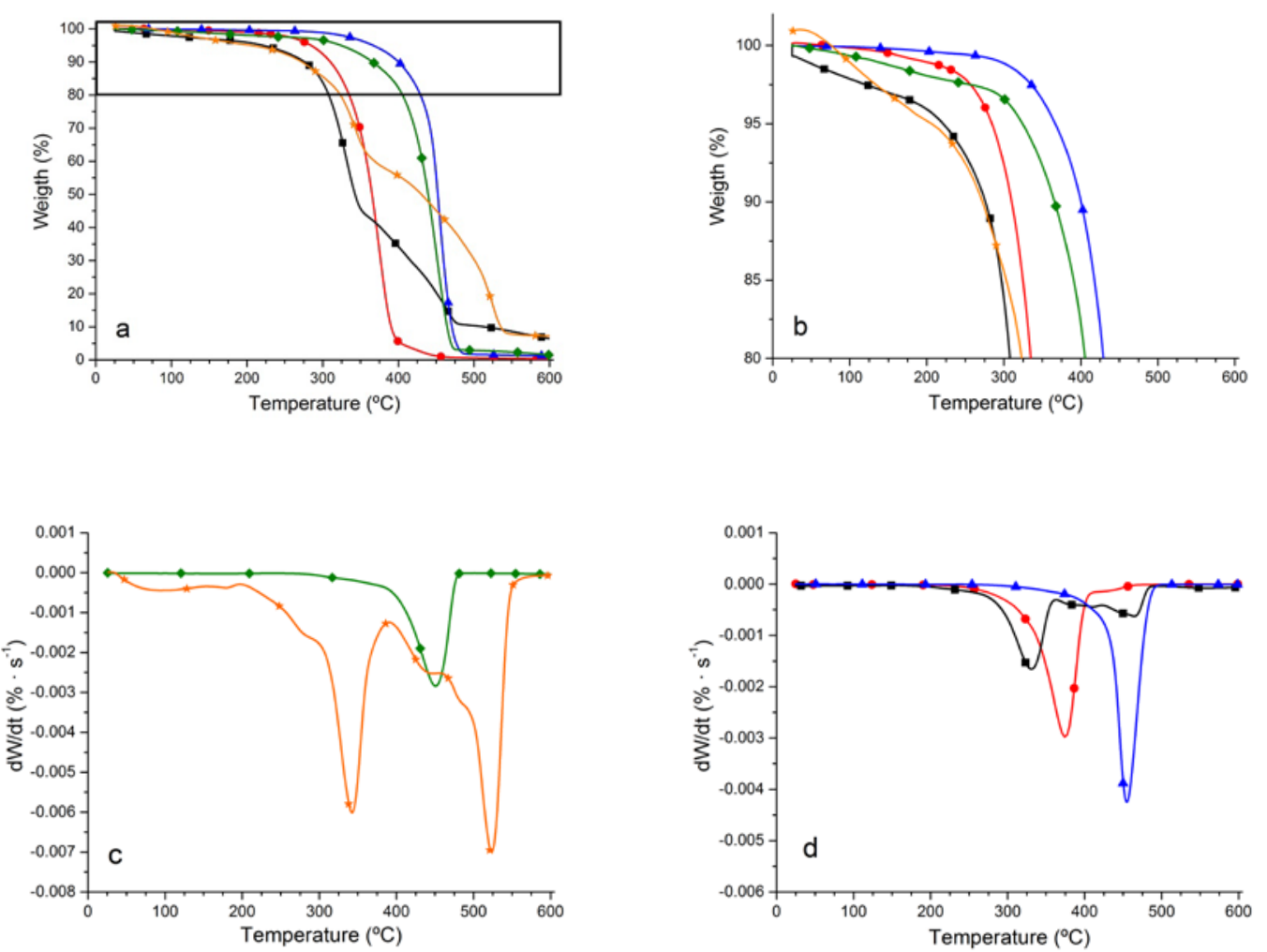

Fig. 1. (a) Full scale TGA, (b) TGA at square region zoom and (c, d) DTG curves for the five ILs obtained in an inert (nitrogen) atmosphere at a heating rate of $10^{\circ} \mathrm{C} / \mathrm{min}:(\mathbf{O})\left[\mathrm{P}_{66614}\right]\left[\left(\mathrm{iC}_{8}\right)_{2} \mathrm{PO}_{2}\right]$, $(\boldsymbol{\square})\left[\mathrm{P}_{66614}\right][\mathrm{BEHP}],(\mathbf{\Delta})\left[\mathrm{P}_{66614}\right][\mathrm{NTf} 2],(\diamond)\left[\mathrm{P}_{44414}\right][\mathrm{DBS}]$ and $(\star)\left[\mathrm{P}_{4442}\right][\mathrm{DEP}]$.

These results are in agreement with others reporting that the thermal stability of ILs is largely determined by the coordinating ability of the anion [76,77]. It is likely that the main goal for achieving weak 
coordinating chemistry is a high degree of charge delocalisation. The charge delocalisation should happen over the entire anion, avoiding individual atoms or groups of atoms with high concentrations of charge, such as oxygen or chlorine atoms. This means that anions with accessible oxygen atoms for binding to the cation should have a stronger coordinating ability than others without available atoms with high concentrations of charge. Alternatively, larger anions (containing more atoms) provoke better delocalisation of the charge and weaker coordination [78]. Taking into account all these considerations, ILs containing anions without accessible oxygen for binding to the cation, such as bis(trifluoromethylsulfonyl)imide or with an aromatic group and larger alkyl chains, such as dodecylbenzenesulfonate, provide a better delocalisation of the charge leading to good thermal stability $[63,76]$. In addition, anion nucleophilicity is another possible approach which should prove useful in predicting quantitative thermal stability trends in ionic liquids $[79,80]$. The pathway with the lowest activation free energy would be expected to be the most nucleophilic [81].

Regarding the more reactive phosphate type ILs ([ $\left.\mathrm{P}_{66614}\right][\mathrm{BEHP}]$ and $\left.\left[\mathrm{P}_{4442}\right][\mathrm{DEP}]\right)$, three stages of weight loss up to $600^{\circ} \mathrm{C}$ were observed when an inert (nitrogen) atmosphere was used: i) 25-200 ${ }^{\circ} \mathrm{C}$, ii) 200-500 ${ }^{\circ} \mathrm{C}$ and iii) $500-600{ }^{\circ} \mathrm{C}$, with the main weight loss being found in the $200-500{ }^{\circ} \mathrm{C}$ case. In this mentioned case, it is possible to find fragments of $\mathrm{H}_{2} \mathrm{O}$, linear hydrocarbons and hydrocarbon arms attached to phosphorus [82]. Since there is no reactive atmosphere, the most abundant fragments should correspond to hydrocarbons with lengths greater than those found in oxidative atmosphere. The absence of a reactive atmosphere makes it impossible for the formation of $\mathrm{P}_{2} \mathrm{O}_{5}, \mathrm{CO}_{2}$ and $\mathrm{H}_{3} \mathrm{PO}_{4}$.

\subsection{Thermo-oxidative decomposition}

When analysing the thermal stability of ILs, a question that should be raised is how to unequivocally define its thermal decomposition temperature. The answer is not direct, even if circumscribed to a single technique, such as TGA. Apart from factors related to the sample itself, such as the presence of moisture and/or impurities (which could lead to a significant decrease in the stability), taking into account the operating factor (type of sample, sample size and heating rate) is also required. This coexistence of different factors limits the comparison of data from different sources [15,77], with the experimental atmosphere used in TGA studies being one of the most important factors affecting the results $[65,83]$. TGA and DTG curves measured in an oxidising atmosphere are shown in Fig. 2. Since the atmosphere 
plays a very important role in the thermal degradation of ILs, the shape of these curves is very different from the curves displayed in Fig. 1.
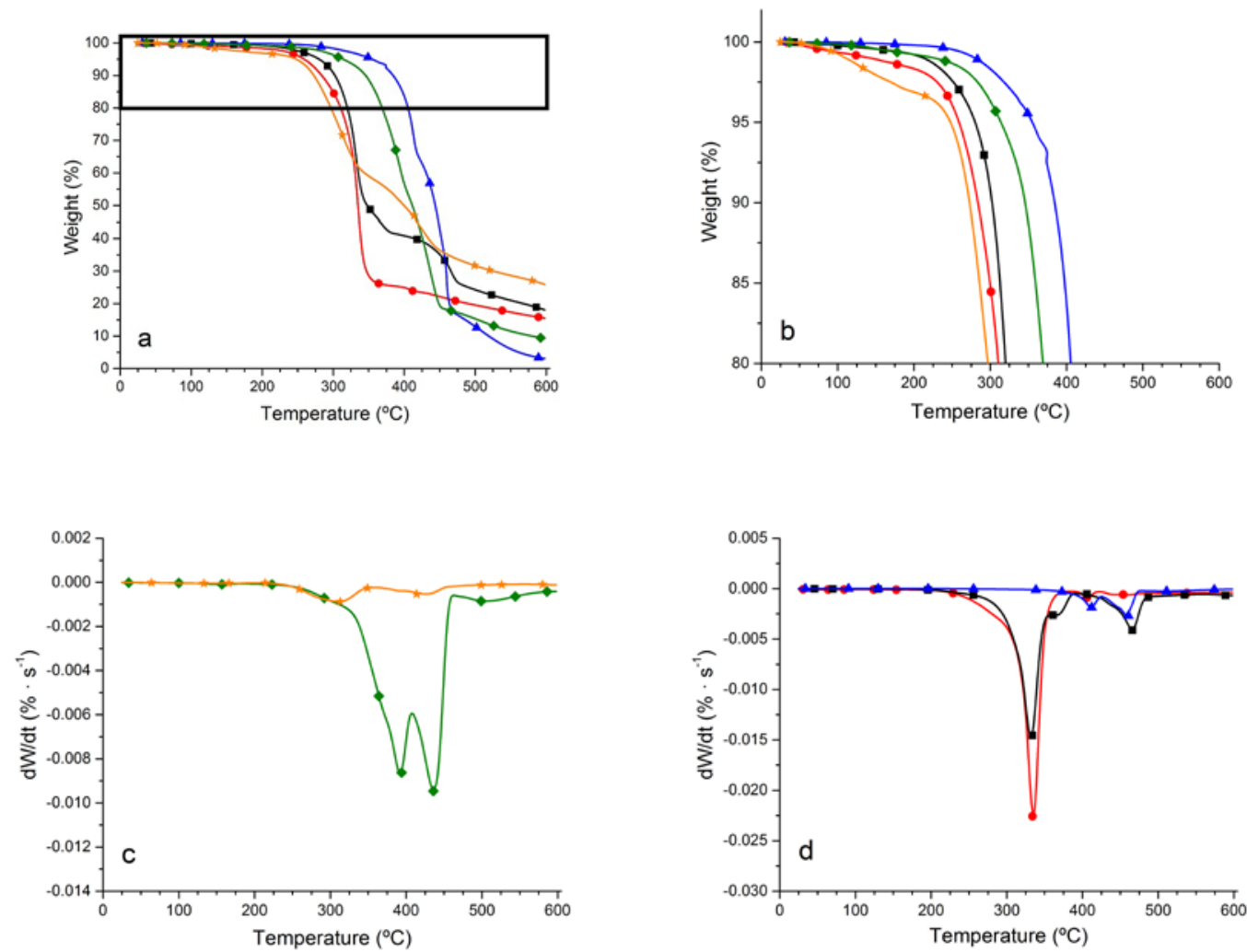

Fig. 2. (a) Full scale TGA, (b) TGA at square region zoom and (c, d) DTG curves for the five ILs obtained in a reactive (oxygen) atmosphere at a heating rate of $10^{\circ} \mathrm{C} / \mathrm{min}$ : $(\bullet)\left[\mathrm{P}_{66614}\right]\left[\left(\mathrm{iC}_{8}\right)_{2} \mathrm{PO}_{2}\right]$,

$$
\left.(\mathbf{\square})\left[\mathrm{P}_{66614}\right][\mathrm{BEHP}],(\mathbf{\Delta})\left[\mathrm{P}_{66614}\right][\mathrm{NTf} 2],(\diamond)\left[\mathrm{P}_{44414}\right][\mathrm{DBS}] \text { and }(\star) \text { [P } \mathrm{P}_{4442}\right][\mathrm{DEP}] \text {. }
$$

According to Keating et al. [82], it is likely that fragments of $\mathrm{H}_{2} \mathrm{O}$, linear hydrocarbons and hydrocarbon arms attached to phosphorus are found when phosphonium-based ILs react from 250 to $400^{\circ} \mathrm{C}$. Thus, linear hydrocarbon fragments of different lengths, such as $\mathrm{CH}_{3}, \mathrm{C}_{2} \mathrm{H}_{5}, \mathrm{C}_{3} \mathrm{H}_{7}, \mathrm{C}_{4} \mathrm{H}_{9}, \mathrm{C}_{5} \mathrm{H}_{11}, \mathrm{C}_{6} \mathrm{H}_{13}$, can be distinguished. Besides, the organophosphorus compounds can be result in intact P-C bonds in which the number and length of the hydrocarbon can be diverse, i.e., $\mathrm{P}\left(\mathrm{CH}_{2}\right)_{3}, \mathrm{P}\left(\mathrm{CH}_{2}\right)_{4}, \mathrm{CH}_{2}=\mathrm{P}\left(\mathrm{CH}_{2} \mathrm{CH}_{2}\right)_{2}$, $\mathrm{CH}_{2}=\mathrm{P}\left(\mathrm{CH}_{2} \mathrm{CH}_{2}\right)_{3}, \mathrm{P}\left(\mathrm{CH}_{2} \mathrm{CH}_{2}\right)_{4}$. It is also probable that the longest hydrocarbon arms attached to phosphorus are present in higher amounts between 400 and $500^{\circ} \mathrm{C}$. Other mass fragments that can be found are $\mathrm{CO}_{2}$ and $\mathrm{H}_{3} \mathrm{PO}_{4}$. The former one results from the oxidation of hydrocarbons, whereas the latter is due to phosphorus oxidation to $\mathrm{P}_{2} \mathrm{O}_{5}$, which yields phosphoric acid in presence of water. Taking into account that $\left[\mathrm{P}_{4442}\right][\mathrm{DEP}] \mathrm{IL}$ has short-length hydrocarbons, the presence of $\mathrm{CH}_{3}, \mathrm{C}_{2} \mathrm{H}_{5}, \mathrm{C}_{3} \mathrm{H}_{7}, \mathrm{P}\left(\mathrm{CH}_{2}\right)_{3}$ and $\mathrm{P}\left(\mathrm{CH}_{2}\right)_{4}$ can be expected. Besides, other fragments such as $\mathrm{CO}_{2}$ and $\mathrm{P}_{2} \mathrm{O}_{5}$ can also be expected. In 
this case, considering that the hydrocarbon chain of the anion is short, the phosphorus is more easily accessible for oxidation to $\mathrm{P}_{2} \mathrm{O}_{5}$. This can explain why the residual content obtained in oxidising atmosphere is very high (25.9\%) in comparison with that found in inert atmosphere.

A data comparison between Figs. 1 and 2 is carried out in Table 2, by collecting several thermogravimetric parameters, such as $\mathrm{T}_{\text {onset }}, \mathrm{T}_{10 \%}, \mathrm{~T}_{\text {peak1 }}, \mathrm{T}_{\text {peak2 }}$ and $\mathrm{Wt}_{\text {total loss }}$ in both inert (nitrogen) and reactive (oxygen) atmospheres. In view of the results, there is a clear influence of the atmosphere on both temperatures of thermal degradation $\left(\mathrm{T}_{\text {onset }}\right.$ and $\left.\mathrm{T}_{10 \%}\right)$ and in the total weight loss $\left(\mathrm{Wt}_{\text {total loss }}\right)$. These mentioned differences between both atmospheres have also been reflected on the DTG curves ( $\mathrm{T}_{\text {peak1 }}$ and

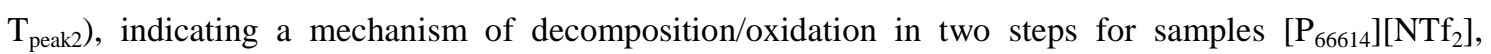
[P $\left.\mathrm{P}_{44414}\right][\mathrm{DBS}]$ (Figs. 2c and 2d) against the one-step thermal decomposition process under nitrogen.

Table 2. Thermal results from dynamic scans in both atmospheres at $10^{\circ} \mathrm{C} / \mathrm{min}$.

\begin{tabular}{|c|c|c|c|c|c|c|}
\hline Ionic Liquids & Atmosphere & $\mathrm{T}_{\text {onset }}\left({ }^{\circ} \mathrm{C}\right)$ & $\mathrm{T}_{10 \%}\left({ }^{\circ} \mathrm{C}\right)$ & $\mathrm{T}_{\text {peak1 }}\left({ }^{\circ} \mathrm{C}\right)$ & $\mathrm{T}_{\text {peak2 }}\left({ }^{\circ} \mathrm{C}\right)$ & $W_{t} t_{\text {total loss* }}(\%)$ \\
\hline \multirow{2}{*}[\mathrm{P}_{66614}]{$\left[(\mathrm{iC} 8)_{2} \mathrm{PO}_{2}\right]$} & $\mathrm{N}_{2}$ & 338 & 313 & 376 & -- & 99.6 \\
\hline & $\mathrm{O}_{2}$ & 320 & 286 & 344 & 390 & 84.6 \\
\hline \multirow{2}{*}[\mathrm{P}_{66614}]{$[\mathrm{BEHP}]$} & $\mathrm{N}_{2}$ & 298 & 276 & 331 & 467 & 93.5 \\
\hline & $\mathrm{O}_{2}$ & 296 & 304 & 339 & 470 & 82.0 \\
\hline \multirow{2}{*}[\mathrm{P}_{66614}]{$\left[\mathrm{NTf}_{2}\right]$} & $\mathrm{N}_{2}$ & 434 & 400 & 456 & -- & 98.8 \\
\hline & $\mathrm{O}_{2}$ & 401 & 388 & 422 & 432 & 96.7 \\
\hline \multirow{2}{*}[\mathrm{P}_{44414}]{$[\mathrm{DBS}]$} & $\mathrm{N}_{2}$ & 414 & 367 & 453 & -- & 98.5 \\
\hline & $\mathrm{O}_{2}$ & 359 & 353 & 401 & 438 & 89.6 \\
\hline \multirow{2}{*}[\mathrm{P}_{4442}]{$[\mathrm{DEP}]$} & $\mathrm{N}_{2}$ & 309 & 272 & 342 & 530 & 92.8 \\
\hline & $\mathrm{O}_{2}$ & 265 & 274 & 312 & 423 & 74.1 \\
\hline
\end{tabular}

*total experiment time: $57.5 \mathrm{~min}$.

Regarding the early weight loss region (Fig.2b), it seems again that the phosphate anion ILs (especially $\left.\left[\mathrm{P}_{4442}\right][\mathrm{DEP}]\right)$ provoke a more pronounced descent, probably related to the water content (analogous to Fig.1b). A comparison of the first the step of weight loss up to $275^{\circ} \mathrm{C}$, depending on the ILs used, using reactive atmosphere $\left(\mathrm{O}_{2}\right)$ and inert one $\left(\mathrm{N}_{2}\right)$ showed that the initial weight losses and average rates were greater in the inert atmosphere than in the oxidising one for all ionic liquids with the exception of $\left[\mathrm{P}_{66614}\right]\left[(\mathrm{iC} 8)_{2} \mathrm{PO}_{2}\right]$. The oxygen presence alters the pathway of thermal degradation by initiating reactions of lower activation energy. This fact suggests that thermal degradation starts earlier in this IL in $\mathrm{O}_{2}$ 
atmosphere (see Table 3). It should be noted that this process is masked by weight loss processes, especially when heating rates above $1.5^{\circ} \mathrm{C} / \mathrm{min}$ were used, as in agreement with Menczel and Prime [84]. Regarding the step of the greatest weight loss in oxidising atmosphere, it took place between $225-285^{\circ} \mathrm{C}$, $200-400^{\circ} \mathrm{C}, 320-500^{\circ} \mathrm{C}, 275-525^{\circ} \mathrm{C}$ and $200-525^{\circ} \mathrm{C}$ for $\left[\mathrm{P}_{66614}\right]\left[(\mathrm{iC} 8)_{2} \mathrm{PO}_{2}\right],\left[\mathrm{P}_{66614}\right][\mathrm{BEHP}],\left[\mathrm{P}_{66614}\right]\left[\mathrm{NTf}_{2}\right]$, $\left[\mathrm{P}_{44414}\right][\mathrm{DBS}]$ and $\left[\mathrm{P}_{4442}\right][\mathrm{DEP}]$, respectively. However, in the presence of nitrogen, the ranges of temperature in which the greatest weight loss occurred were generally wider, namely $225-475^{\circ} \mathrm{C}, 200$ $500^{\circ} \mathrm{C}, 200-500^{\circ} \mathrm{C}, 275-525^{\circ} \mathrm{C}$ and $200-525^{\circ} \mathrm{C}$ for the same ILs. Therefore, the decomposition temperature and thermal stability of ILs is strongly dependent on the selected anion [16]. In this case, the rate of weight loss does not show a clear tendency, possibly attributed to the different mechanisms for the degradation. Thus, the oxidation tends to show various steps, commonly two, whereas the decomposition exhibits usually one step. Hence, when thermo oxidative processes are involved, decomposition and oxidation take place concurrently. This implies both weight gain associated with the oxidation and weight loss due to the decomposition of the ILs, and this accounts for the declining tendency in mass over this temperature range. However, when nitrogen is employed, the weight is almost completely lost in the previous stage/stages.

Table 3. Mass changes and rates in the first step of weight loss of the different ILs between $25-275^{\circ} \mathrm{C}$.

\begin{tabular}{|c|c|c|c|c|c|c|}
\hline \multirow{3}{*}{ Ionic Liquid } & \multirow{2}{*}{\multicolumn{3}{|c|}{ Reactive atmosphere $\left(\mathrm{O}_{2}\right)$}} & & & \\
\hline & & & & \multicolumn{3}{|c|}{ Inert Atmosphere $\left(\mathrm{N}_{2}\right)$} \\
\hline & $\begin{array}{c}\mathrm{T}^{\mathrm{a}} \\
\text { Range } \\
\left({ }^{\circ} \mathrm{C}\right)\end{array}$ & $\begin{array}{c}\text { Weight } \\
\text { loss } \\
(\%)\end{array}$ & $\begin{array}{c}\text { Rate } \\
\left(\% \cdot{ }^{\circ} \mathrm{C}^{-1}\right)\end{array}$ & $\begin{array}{c}\mathrm{T}^{\mathrm{a}} \\
\text { range } \\
\left({ }^{\circ} \mathrm{C}\right)\end{array}$ & $\begin{array}{l}\text { Weight } \\
\text { loss (\%) }\end{array}$ & $\begin{array}{c}\text { Rate } \\
\left(\% \cdot{ }^{\circ} \mathrm{C}^{-1}\right)\end{array}$ \\
\hline$\left[\mathrm{P}_{66614}\right]\left[\left(\mathrm{iC}_{8}\right)_{2} \mathrm{PO}_{2}\right]$ & $25-225$ & 2.31 & $1.15 \cdot 10^{-2}$ & $25-225$ & 1.43 & $7.20 \cdot 10^{-3}$ \\
\hline$\left[P_{66614}\right][B E H P]$ & $25-200$ & 0.78 & $4.50 \cdot 10^{-3}$ & $25-200$ & 4.08 & $2.33 \cdot 10^{-2}$ \\
\hline$\left[\mathrm{P}_{66614}\right]\left[\mathrm{NTf}_{2}\right]$ & $25-200$ & 0.19 & $1.10 \cdot 10^{-3}$ & $25-200$ & 0.38 & $2.10 \cdot 10^{-3}$ \\
\hline$\left[P_{44414}\right][D B S]$ & $25-275$ & 2.03 & $8.1 \cdot 10^{-3}$ & $25-275$ & 2.71 & $1.08 \cdot 10^{-2}$ \\
\hline$\left[\mathbf{P}_{4442}\right][D E P]$ & $25-200$ & 3.10 & $1.77 \cdot 10^{-2}$ & $25-200$ & 5.70 & $3.26 \cdot 10^{-2}$ \\
\hline
\end{tabular}

It is also noteworthy that the amount of residue obtained after TGA is larger when reactive atmosphere was employed (see Table 4) and therefore $\mathrm{Wt}_{\text {total loss }}$ is smaller under oxidative conditions. This is explained by the weight gain during the oxidation process. Besides, ILs containing phosphorus in both the cationic and anionic moiety, also presented greater values of residual content. This is due to the oxidation of phosphorus to $\mathrm{P}_{2} \mathrm{O}_{5}$, which partly remained in the residue. Such a result is in agreement with the data 
reported by Keating et al. [82], who found Phosphorus in the ash of $\left[\mathrm{P}_{66614}\right]\left[\mathrm{NTf}_{2}\right]$ and $\left[\mathrm{P}_{66614}\right]\left[(\mathrm{iC} 8)_{2} \mathrm{PO}_{2}\right]$ after thermogravimetric analysis in the range of $20-740^{\circ} \mathrm{C}$.

Table 4. Residual content of different ILs after TGA at $600^{\circ} \mathrm{C}$

\begin{tabular}{|c|c|c|}
\hline & Reactive atmosphere $\left(\mathrm{O}_{2}\right)$ & Inert Atmosphere $\left(\mathrm{N}_{2}\right)$ \\
\hline Ionic Liquid & Residue at $600^{\circ} \mathrm{C}(\%)$ & Residue at $600^{\circ} \mathrm{C}(\%)$ \\
\hline$\left[\mathrm{P}_{66614}\right]\left[\left(\mathrm{iC}_{8}\right)_{2} \mathrm{PO}_{2}\right]$ & 15.4 & 0.35 \\
\hline$\left[\mathbf{P}_{66614}\right][\mathrm{BEHP}]$ & 18.1 & 6.5 \\
\hline$\left[P_{66614}\right]\left[N_{T F}\right]$ & 3.3 & 1.2 \\
\hline$\left[\mathbf{P}_{44414}\right][\mathrm{DBS}]$ & 10.4 & 1.5 \\
\hline$\left[\mathrm{P}_{4442}\right][\mathrm{DEP}]$ & 25.9 & 7.2 \\
\hline
\end{tabular}

Fig. 3 shows the comparison of SDTA (single differential thermal analysis) curves in both atmospheres for all ILs tested.
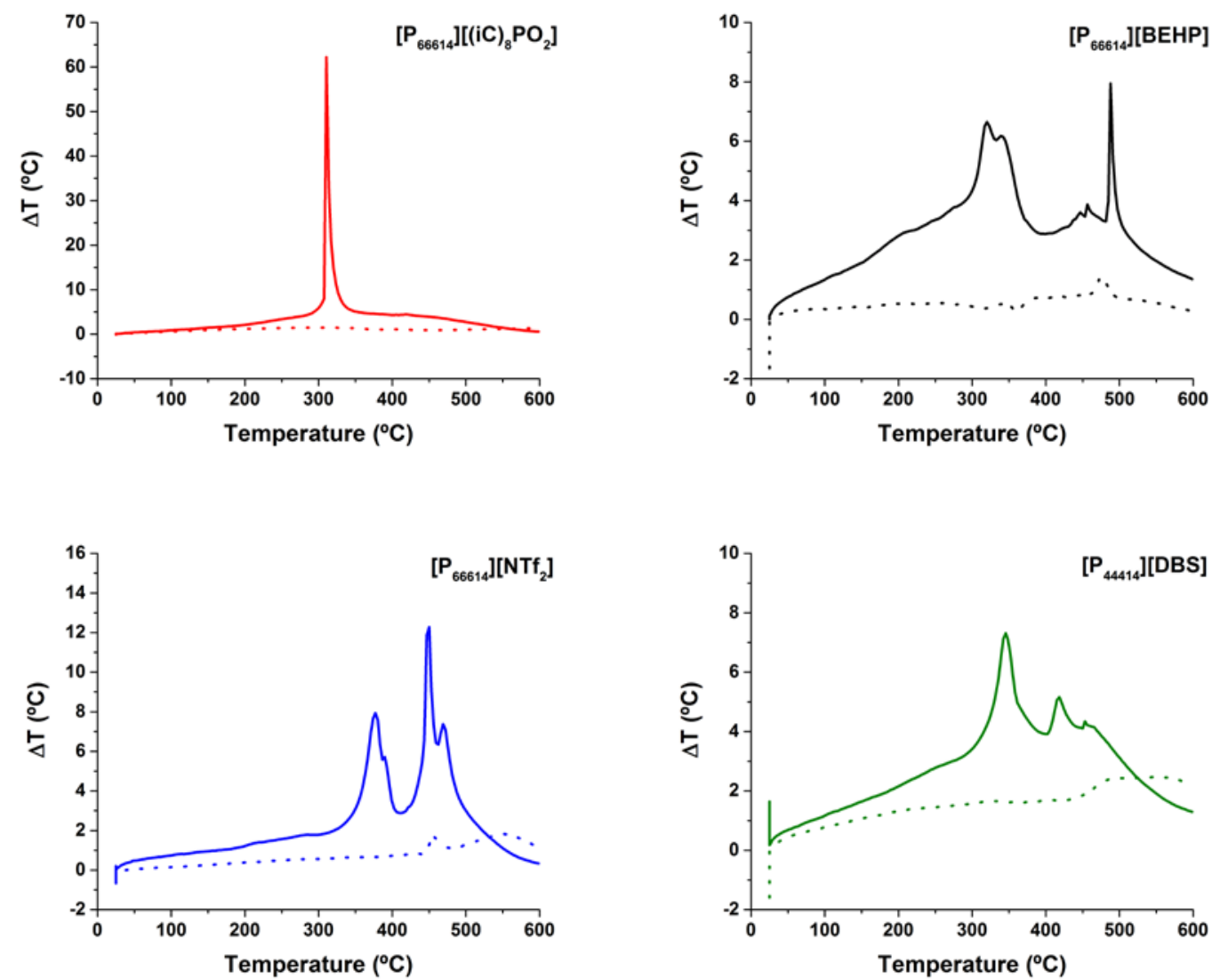


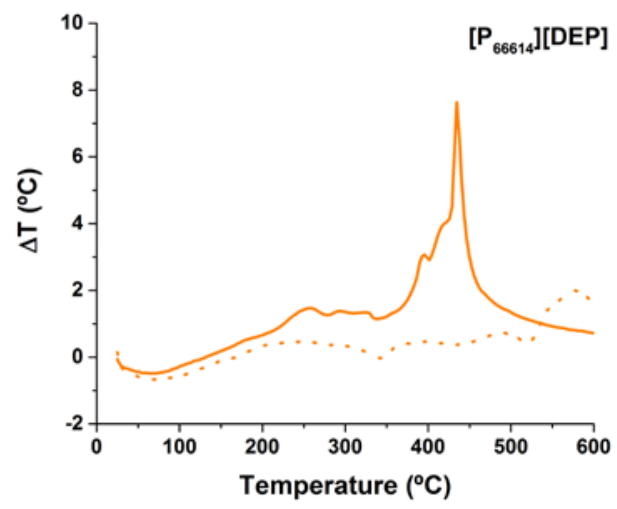

Fig. 3. SDTA for all ILs obtained in both inert (nitrogen, ---) and reactive (oxygen, - -) atmospheres at a heating rate of $10^{\circ} \mathrm{C} / \mathrm{min}$.

In these curves, the ILs under study and an inert reference are conducted to undergo the same thermal cycles, recording differences in the temperature $(\Delta T)$ and identifying physical and chemical phenomena causing heat changes (exothermic or endothermic), such as adsorption (exothermic), crystallisation (exothermic), vaporisation (endothermic), oxidation (exothermic) and so on. The mechanistic differences between thermal and thermo-oxidative degradation is clear in view of these results. The decomposition was determined to be endothermic if the SDTA temperature gradient was negative. Whilst in an inert (nitrogen) atmosphere the thermal decomposition implies a very low signal, exothermic signal measurement in the reactive (oxygen) atmosphere is related with an overlapped oxidation process.

\subsection{Kinetic analysis}

The above mentioned thermal stabilities have been evaluating using TGA at a single linear heating rate $\left(10^{\circ} \mathrm{C} / \mathrm{min}\right)$. The kinetics and mechanism of the thermal decomposition reaction were evaluated from the TG data according to the ICTAC Kinetics Committee recommendations [85,86]. As previously discussed, isothermal studies have shown that ILs exhibit appreciable decomposition at temperatures significantly lower than the values indicated by the onset temperature decomposition calculated from scanning TGA experiments. Therefore, in order to fully evaluate the long-term thermal stabilities and thermal decomposition of the studied ILs, it is necessary to identify global kinetics models.

In this research study, several parameters such as the activation energy (E), the conversion and the degradation decomposition time were estimated as a function of temperature using both TG experimental data and KAS model-free kinetics (in an oxygen atmosphere). As model-free kinetics require at least 
three dynamic curves with different heating rates, TGA curves obtained at 5, 10 and $20^{\circ} \mathrm{C} / \mathrm{min}$ are shown in Fig. 4.
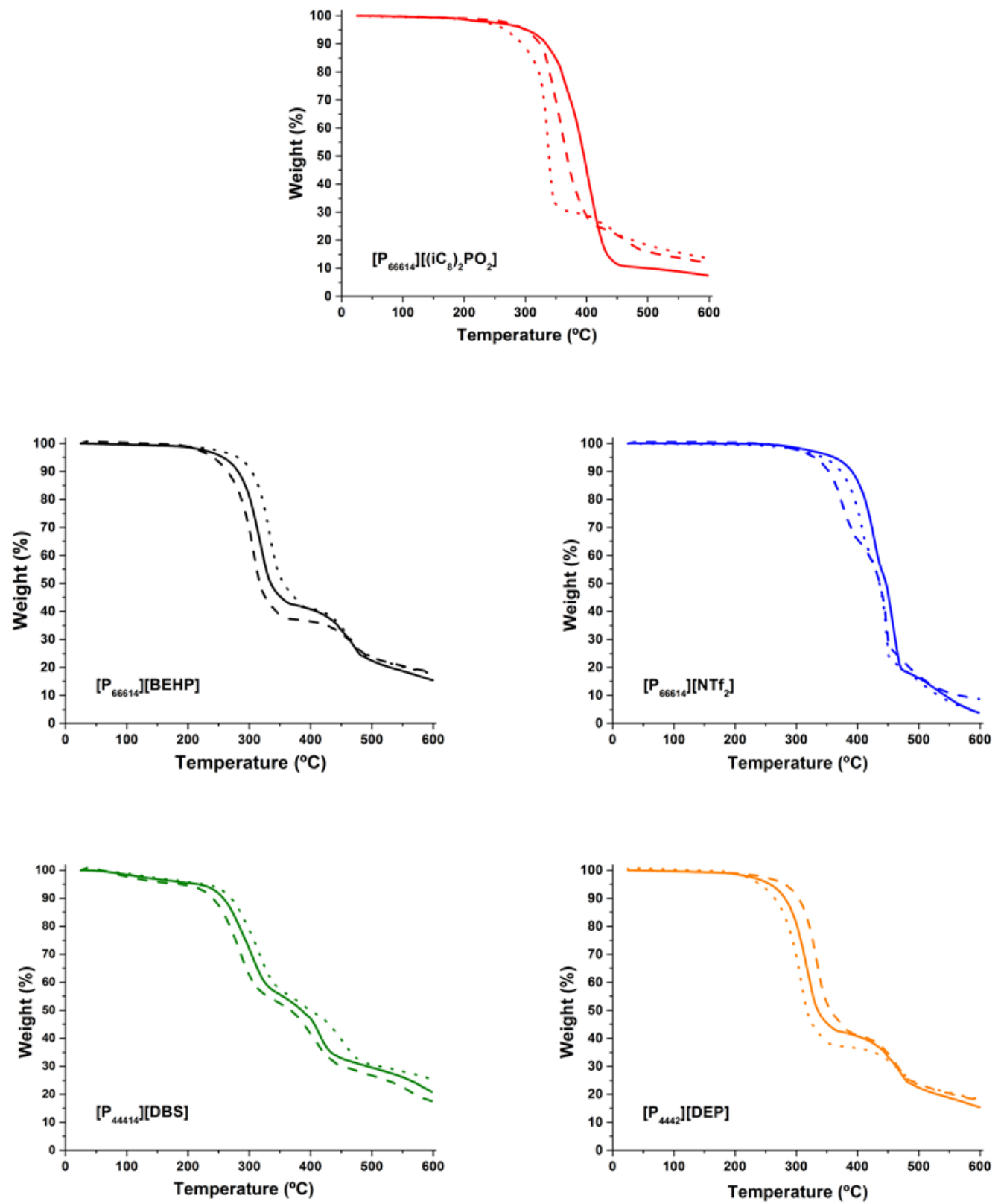

Fig. 4. TGA of all ILs studied in a reactive (oxygen) atmosphere at heating rates of

$$
5 \text { (---), } 10(-) \text { and } 20^{\circ} \mathrm{C} / \mathrm{min}(\cdots) \text {. }
$$

Fig.4 shows the behavior of $\left[\mathrm{P}_{44414}\right][\mathrm{DBS}]$ and $\left[\mathrm{P}_{66614}\right][\mathrm{BEHP}]$ samples at lower heating rates, where the temperature values shift lower and consequently the total mass loss increases [87]. On the other hand, $\left[\mathrm{P}_{4442}\right][\mathrm{DEP}]$ behaved different: higher heating rates seem to activate the decomposition reaction and the total mass loss growths. Finally, it is hard to extract conclusions from heating rate variation with 
$\left[\mathrm{P}_{66614}\right]\left[\mathrm{NTf}_{2}\right]$ and $\left[\mathrm{P}_{66614}\right]\left[\left(\mathrm{iC}_{8}\right)_{2} \mathrm{PO}_{2}\right]$ samples. The model-free approach to kinetic analysis rests upon the isoconversional principle, according to which the reaction rate at a constant extent of conversion is only a function of temperature. This fact implies that curves plotted at different heating rates cannot intersect. If this issue happens, data obtained could lead to unrealistic conclusions [88]. In this research, the crossing curves issue happens at temperatures higher than $420^{\circ} \mathrm{C}$. This fact can be observed in all samples and it is related to the wt.\% obtained at the end of pyrolysis (char formation yield). Therefore, an interval of temperatures $200-420{ }^{\circ} \mathrm{C}$ was chosen for model-free kinetics calculations. Fig. 5 shows the apparent activation energy versus thermal conversion process obtained by the KAS model-free kinetics methodology.
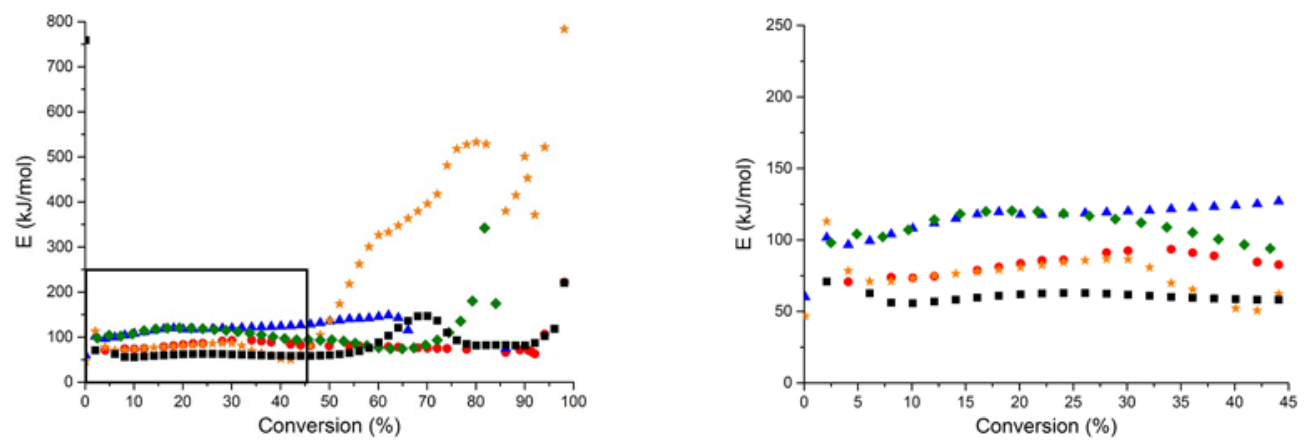

Fig. 5. Apparent activation energy as a function of conversion derived from experiments using 5, 10 and $20{ }^{\circ} \mathrm{C} / \mathrm{min}$ heating rates for the five ILs: $(\mathbf{O})\left[\mathrm{P}_{66614}\right]\left[\left(\mathrm{iC}_{8}\right)_{2} \mathrm{PO}_{2}\right],(\boldsymbol{\square})\left[\mathrm{P}_{66614}\right][\mathrm{BEHP}],(\mathbf{\Delta})\left[\mathrm{P}_{66614}\right][\mathrm{NTf} 2]$, $(\diamond)\left[\mathrm{P}_{44414}\right][\mathrm{DBS}]$ and $(\star)\left[\mathrm{P}_{4442}\right][\mathrm{DEP}]$. Full scale image (left) and zoom at square region (right).

In general, constant activation energy values should be expected in the case of a single reaction. However, the E profile obtained from Fig. 5 indicates that the decomposition mechanism is a function of the conversion degree. In addition, Fig.5 (right) shows that the activation energy (E) remained practically constant at low conversions (2-40\%), with values between 50 and $120 \mathrm{~kJ} / \mathrm{mol}$. Table 5 exhibites the average values and their standard deviations. Therefore, the trend of relative nucleophilicities of the anions in this research work is (in decreasing nucleophilic strength): $\left[\mathrm{P}_{66614}\right][\mathrm{BEHP}]>\left[\mathrm{P}_{4442}\right][\mathrm{DEP}]>$ $\left[\mathrm{P}_{66614}\right]\left[\left(\mathrm{iC}_{8}\right)_{2} \mathrm{PO}_{2}\right]>\left[\mathrm{P}_{44414}\right][\mathrm{DBS}]>\left[\mathrm{P}_{66614}\right]\left[\mathrm{NTf}_{2}\right]$, according to the activation energy (E) values (Table 5). These results are in agreement with the delocalisation charge approach, where $\left[\mathrm{P}_{44414}\right][\mathrm{DBS}]$ and $\left[\mathrm{P}_{66614}\right]\left[\mathrm{NTf}_{2}\right]$ are the less nucleophilic ILs and therefore the most thermally stable ones. 
Table 5. Apparent activation energy values $(0.02<\alpha<0.4)$ for the five ILs.

\begin{tabular}{cc}
\hline Ionic liquids & $\mathbf{E}$ (kJ/mol) \\
\hline$\left[\mathrm{P}_{66614}\right]\left[\left(\mathrm{iC}_{8}\right)_{2} \mathrm{PO}_{2}\right]$ & $81 \pm 7$ \\
{$\left[\mathrm{P}_{66614}\right][\mathrm{BEHP}]$} & $60 \pm 3$ \\
{$\left[\mathrm{P}_{66614}\right]\left[\mathrm{NTf}_{2}\right]$} & $115 \pm 6$ \\
{$\left[\mathrm{P}_{44414}\right][\mathrm{DBS}]$} & $113 \pm 8$ \\
{$\left[\mathrm{P}_{4442}\right][\mathrm{DEP}]$} & $79 \pm 5$ \\
\hline
\end{tabular}

In order to provide a more realistic description of the thermal stability of these samples, kinetic analysis was performed in oxidising conditions by application of the model-free KAS isoconversional method. This methodology allows one to determine the change in the apparent activation energy during the thermo-oxidative process without choosing the reaction model. Results are shown in Fig. 6.
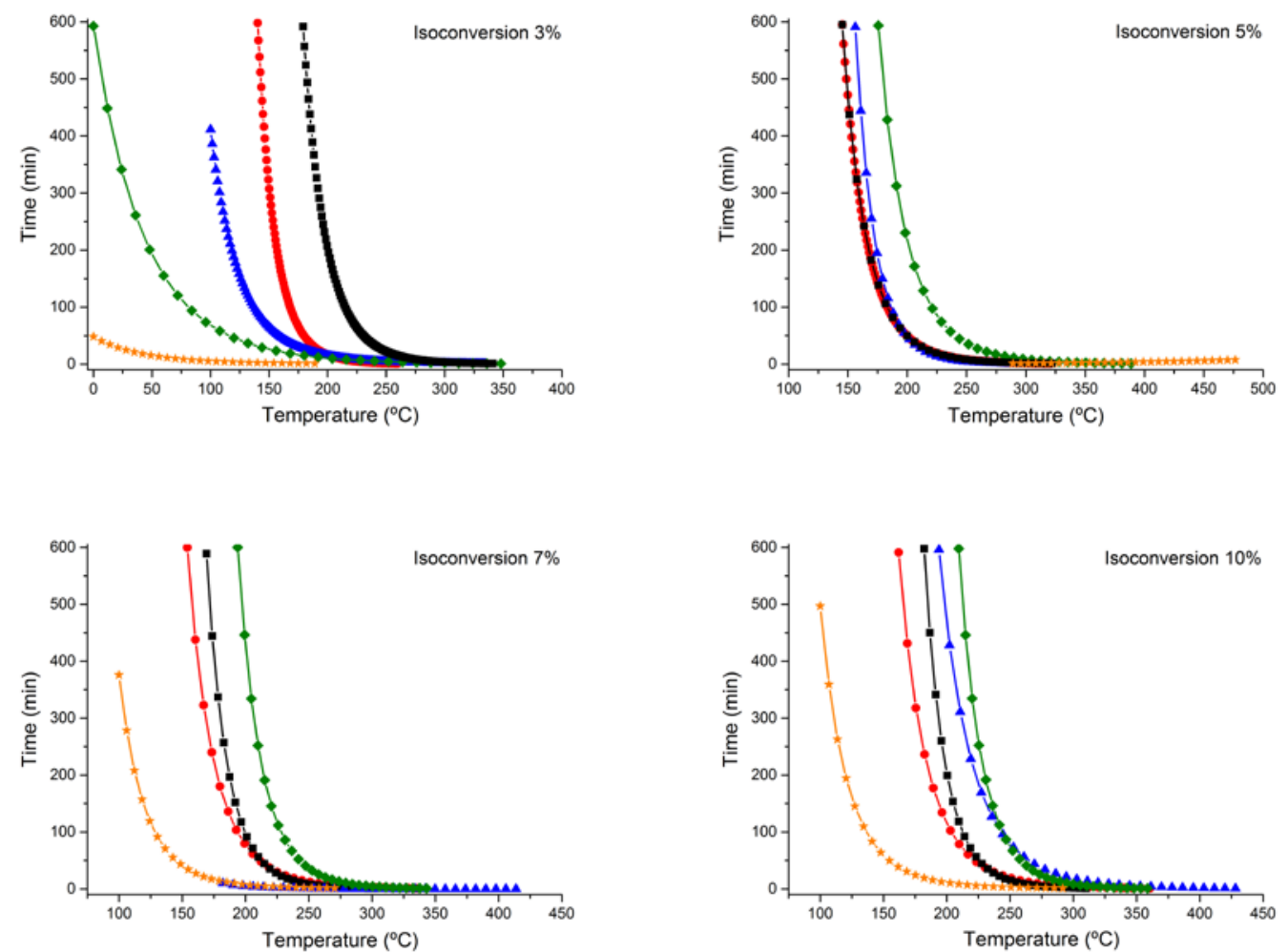

Fig. 6. Estimated isoconversional curves at 3, 5, 7 and $10 \%$ of conversion for the five ILs:

(O) $\left[\mathrm{P}_{66614}\right]\left[\left(\mathrm{iC}_{8}\right)_{2} \mathrm{PO}_{2}\right],(\mathbf{\square})\left[\mathrm{P}_{66614}\right][\mathrm{BEHP}],(\boldsymbol{\Delta})\left[\mathrm{P}_{66614}\right][\mathrm{NTf} 2],(\diamond)\left[\mathrm{P}_{44414}\right][\mathrm{DBS}]$ and $(\star)$

$$
\left[\mathrm{P}_{4442}\right][\mathrm{DEP}] \text {. }
$$

From Fig. 6, it is possible to estimate the time required for a fixed mass loss (conversion) of the ionic liquid at a given temperature. If $200^{\circ} \mathrm{C}$ is used, $\left[\mathrm{P}_{4442}\right][\mathrm{DEP}]$ reached $10 \%$ conversion in about 25 min, whereas $\left[\mathrm{P}_{66614}\right]\left[\left(\mathrm{iC}_{8}\right)_{2} \mathrm{PO}_{2}\right]$ and $\left[\mathrm{P}_{66614}\right][\mathrm{BEHP}]$ needed more than 100 min. Finally, $\left[\mathrm{P}_{66614}\right]\left[\mathrm{NTf}_{2}\right]$ and 
[P $\left.\mathrm{P}_{44414}\right][\mathrm{DBS}]$ did not achieve the $10 \%$ mark in the total duration of the test $(600 \mathrm{~min})$. The analysis would be similar for the others conversion rates (3\%, $5 \%$ and $7 \%$ ). In addition, it is possible to predict the sample behaviour at isothermal conditions. The model-free methodology allows one to estimate the sample performance in isothermal conditions. In order to check these results, some isothermal experiments were carried out for the $\left[\mathrm{P}_{66614}\right]\left[\left(\mathrm{iC}_{8}\right)_{2} \mathrm{PO}_{2}\right]$ sample (Fig. 7). Isothermal experiments indicate that thermo-oxidative decomposition reaches values of 6,22 and $23 \%$ of conversion when the sample is heated at 200, 225 and $250{ }^{\circ} \mathrm{C}$, respectively, for $90 \mathrm{~min}$. In addition, it is possible to predict the sample behaviour in isothermal conditions at a given temperature $\left(T_{0}\right)$ by using Eq. (10) with non-isothermal kinetic data. In order to solve the mentioned equation, the integral is determined using the approximate formula obtained by Wanjun et al. [89]. Thus, the temperature (in ${ }^{\circ} \mathrm{C}$ ) at which each conversion value is reached in the selected time could be obtained [66]. The deviations between experimental and model values may be linked to not taking into account the evaporation kinetics. Anyway, From Fig. 6 data, results obtained at low conversions $(\alpha<0.1)$ by the application of the model-free methodology with $\mathrm{T}_{0}=200^{\circ} \mathrm{C}$ are in good agreement with those obtained by experimental isothermal analysis. Although this result seems to support the decision concerning evaporation, further research considering this evaporation kinetic should be conducted in all temperature range to validate completely the model [65]. On the other hand, differences between 200 and 225 isotherms prove the previous statement regarding the overestimation of long-term thermal stability of the ILs with conducting standard TGA experiments. If the $320{ }^{\circ} \mathrm{C}$ value of $\mathrm{T}_{\text {onset }}$ calculated from classic dynamic TGA analysis were precise, the 225 and 250 isotherms should be closer to $200^{\circ} \mathrm{C}$ one.

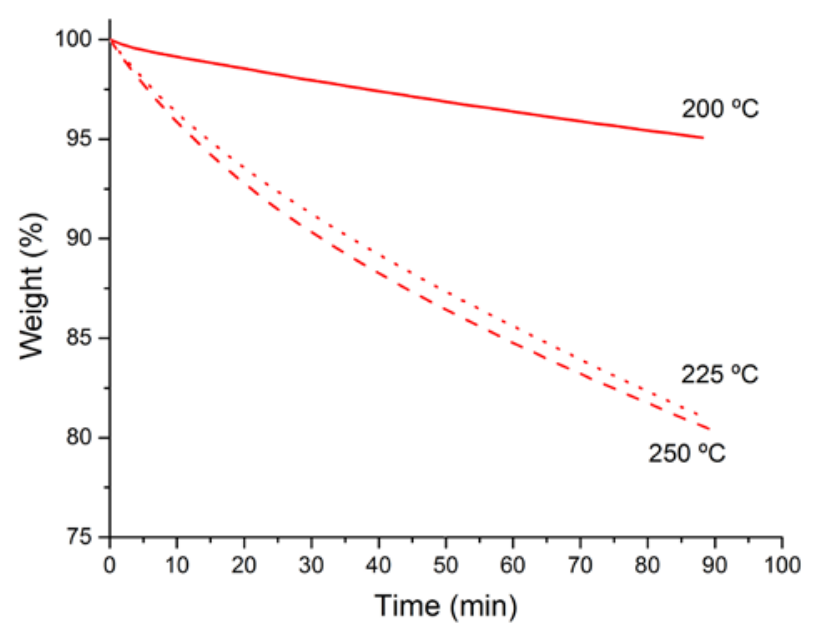

Fig. 7. Isothermal scans for $\left[\mathrm{P}_{66614}\right]\left[\left(\mathrm{iC}_{8}\right)_{2} \mathrm{PO}_{2}\right]$ in a reactive (oxygen) atmosphere. 


\section{Conclusions}

The thermal degradation of five phosphonium cation-based ILs, $\left[\mathrm{P}_{66614}\right][\mathrm{BEHP}],\left[\mathrm{P}_{66614}\right]\left[\left(\mathrm{iC}_{8}\right)_{2} \mathrm{PO}_{2}\right]$, $\left[\mathrm{P}_{66614}\right]\left[\mathrm{NTf}_{2}\right],\left[\mathrm{P}_{44414}\right][\mathrm{DBS}]$ and $\left[\mathrm{P}_{4442}\right][\mathrm{DEP}]$, was studied in both nitrogen (inert) and oxygen (reactive) atmospheres using dynamic and isothermal approaches. From the obtained results, the following conclusions can be drawn:

- Thermal degradation of ILs is clearly dominated by the nature of the anion, endowing the weakly-coordinating-anion ILs (such as $\left[\mathrm{NTf}_{2}\right]$ and [DBS] based) with a great thermal stability. On the basis that the pathway with the lowest activation free energy (E) would be expected to be the most nucleophilic, the trend in decreasing nucleophilic strength is as follows: $\left[\mathrm{P}_{66614}\right][\mathrm{BEHP}]$ $>\left[\mathrm{P}_{4442}\right][\mathrm{DEP}]>\left[\mathrm{P}_{66614}\right]\left[\left(\mathrm{iC}_{8}\right)_{2} \mathrm{PO}_{2}\right]>\left[\mathrm{P}_{44414}\right][\mathrm{DBS}]>\left[\mathrm{P}_{66614}\right]\left[\mathrm{NTf}_{2}\right]$. Therefore, both approaches are in good agreement.

- Although the atmosphere has a clear influence on the thermal degradation mechanism, the trend of the thermal stability among different samples did not change. Both temperatures of thermal degradation $\left(\mathrm{T}_{\text {onset }}\right.$ and $\left.\mathrm{T}_{10 \%}\right)$ presented the $\left[\mathrm{P}_{66614}\right]\left[\mathrm{NTf}_{2}\right]$ and $\left[\mathrm{P}_{44414}\right][\mathrm{DBS}]$ as the most thermal stable ILs in both pyrolytic and oxidising conditions.

- Despite of the fact that the decomposition mechanism is a function of the conversion degree, the activation energy (E) remained practically constant at low conversions, with values ranging from 60-115 kJ/mol for all ILs studied.

- $\quad$ The long-term thermal stability of the ILs is also overestimated with conducting standard TGA experiments; so the use of isoconversional methods is more appropriate.

- The results from both the application of the model-free methodology and the isothermal experiments are in good agreement especially at low conversions, so the former can be used to predict at lower costs the long-term thermal stability.

- The determination of thermal models, especially those which can predict the long-term thermal stability, is an interesting research topic from lubrication science approach in order to predict the lifetime of lubricants and additives.

- The physicochemical properties of phosphonim cation-based ILs (conferred by the size, symmetry and structure of their ions) combined with an excellent tribological behaviour make them excellent candidates for being used as a lubricant additive. The utilization of this kind of 
substances as an additive in motor oils should take into account current and future specifications for motor oils (e.g. PC-11, ILSAC GF-5 and ILSAC GF-6) which limit phosphorus concentration under 800 ppm.

\section{Nomenclature}

\begin{tabular}{|c|c|c|}
\hline A & $\left(\mathrm{m}^{3 \cdot} \mathrm{mol}^{-1}\right)^{\mathrm{n}-1} \mathrm{~s}^{-1}$ & Pre-exponential factor \\
\hline $\mathbf{E}$ & $\mathrm{kJ} / \mathrm{mol}$ & Activation Energy \\
\hline $\mathrm{M}_{\mathrm{IL}}$ & mol & Molar mass of the ionic liquid \\
\hline B & $\mathrm{m} / \mathrm{s}$ & Mass transfer coefficient \\
\hline A & $\mathrm{m}^{2}$ & Surface area in contact with the gas phase \\
\hline $\mathrm{p}_{\mathrm{vap}}$ & $\mathrm{Pa}$ & Vapour pressure \\
\hline $\mathbf{f}(\alpha)$ & - & Reaction model \\
\hline $\mathbf{k}(\mathbf{T})$ & $\mathrm{J} / \mathrm{K}$ & Temperature dependent constant \\
\hline $\mathbf{R}$ & $\mathrm{J} / \mathrm{K} / \mathrm{mol}$ & Gas constant \\
\hline $\mathbf{t}$ & s & Time \\
\hline $\mathbf{T}$ & ${ }^{\circ} \mathrm{C}$ & Temperature \\
\hline $\mathbf{T}_{\text {on }}$ & ${ }^{\circ} \mathrm{C}$ & Onset Temperature \\
\hline $\mathbf{T}_{10}$ & ${ }^{\circ} \mathrm{C}$ & Temperature at $10 \%$ of mass loss \\
\hline $\mathbf{T}_{\mathbf{0}}$ & ${ }^{\circ} \mathrm{C}$ & Arbitrary Temperature to a given extent of reaction, $\alpha$ \\
\hline $\mathbf{m}_{\mathbf{i}}$ & $\mathrm{kg}$ & Initial mass \\
\hline $\mathbf{m}_{\mathbf{f}}$ & $\mathrm{kg}$ & Final mass \\
\hline $\mathbf{m}_{\mathbf{t}}$ & $\mathrm{kg}$ & Mass at given time, $\mathrm{t}$ \\
\hline$\alpha$ & - & Extent of reaction \\
\hline$\beta$ & ${ }^{\circ} \mathrm{C} / \mathrm{min}$ & Heating rate \\
\hline
\end{tabular}

\section{Acknowledgements}

The authors would like to thank to the Ministry of Economy and Competitiveness (Spain) and FICYT (Foundation for the Promotion in Asturias of the Applied Scientific Research and Technology) for supporting the research projects STARLUBE (DPI2013-48348-C2-1-R) and GRUPIN14-023, respectively, under the framework this research was developed. The Unit of Thermal Tests and Elemental 
Analysis from the Scientific-Technical Services at the University of Oviedo as well as Dr. Paula Oulego Blanco are also acknowledged.

\section{References}

[1] Guo F, Zhang S, Wang J, Teng B, Zhang T, Fan M. Synthesis and applications of ionic liquids in clean energy and environment: A review. Curr. Org. Chem. 2015;19(5):455-68. doi:10.2174/1385272819666150114235649.

[2] Olivier-Bourbigou H, Magna L, Morvan D. Ionic liquids and catalysis: Recent progress from knowledge to applications. Appl. Catal. A Gen. 2010;373:1-56. doi:10.1016/j.apcata.2009.10.008.

[3] Carda-Broch S, Berthod A, Angel MJR-. Ionic liquids in separation techniques. J. Chromatogr. A 2008;1184:6-18. doi:10.1016/j.chroma.2007.11.109.

[4] Zhou F, Liang Y, Liu W. Ionic liquid lubricants: Designed chemistry for engineering applications. Chem. Soc. Rev. 2009;38:2590-9. doi:10.1039/b817899m.

[5] Keskin S, Kayrak-Talay D, Akman U, Hortaçsu Ö. A review of ionic liquids towards supercritical fluid applications. J. Supercrit. Fluids 2007;43:150-80. doi:10.1016/j.supflu.2007.05.013.

[6] Bermúdez MD, Jiménez AE, Sanes J, Carrión FJ. Ionic liquids as advanced lubricant fluids. Molecules 2009;14:2888-908. doi:10.3390/molecules14082888.

[7] Chiappe C, Pieraccini D. Ionic liquids: Solvent properties and organic reactivity. J. Phys. Org. Chem. 2004;18:275-97. doi: 10.1002/poc.863.

[8] Poole CF, Lenca N. Green sample-preparation methods using room-temperature ionic liquids for the chromatographic analysis of organic compounds. TrAC - Trends Anal. Chem. 2015;71:144-56. doi:10.1016/j.trac.2014.08.018.

[9] Gali M, Lewandowski A, St I. Ionic liquids as electrolytes. Electrochim. Acta 2006;51:5567-80. doi:10.1016/j.electacta.2006.03.016.

[10] Salgado J, Villanueva M, Parajó JJ, Fernández J. Long-term thermal stability of five imidazolium ionic liquids. J. Chem. Thermodyn. 2013;65:184-90. doi:10.1016/j.jct.2013.05.049.

[11] Paduszynski K, Okuniewski M, Domanska U. An effect of cation functionalization on thermophysical properties of ionic liquids and solubility of glucose in them - Measurements and PCSAFT calculations. J. Chem. Thermodyn. 2016;92:81-90. doi:10.1016/j.jct.2015.07.019. 
[12] Wei J, Chang C, Zhang Y, Hou S, Fang D, Guan W. Prediction of thermophysical properties of novel ionic liquids based on serine [Cnmim][Ser] $(n=3,4)$ using semiempirical methods. J. Chem. Thermodyn. 2015;90:310-6. doi:10.1016/j.jct.2015.04.029.

[13] Green MD, Schreiner C, Long TE. Thermal, rheological, and ion-transport properties of phosphonium-based ionic liquids. J. Phys. Chem. 2011:13829-35. doi:dx.doi.org/10.1021/jp206138b.

[14] Bhattacharjee A, Lopes-da-Silva JA, Freire MG, Coutinho JAP, Carvalho PJ. Thermophysical properties of phosphonium-based ionic liquids. Fluid Phase Equilib. 2015;400:103-13. doi:10.1016/j.fluid.2015.05.009.

[15] Ferreira AF, Simões PN, Ferreira AGM. Quaternary phosphonium-based ionic liquids: Thermal stability and heat capacity of the liquid phase. J. Chem. Thermodyn. 2012;45:16-27. doi:10.1016/j.jct.2011.08.019.

[16] Fraser KJ, MacFarlane DR. Phosphonium-based ionic liquids: An overview. Aust. J. Chem. 2009;62:309-21. doi:10.1071/CH08558.

[17] Gamlin C, Dutta N, Roy Choudhury N, Kehoe D, Matisons J. Evaluation of kinetic parameters of thermal and oxidative decomposition of base oils by conventional, isothermal and modulated TGA, and pressure DSC. Thermochim. Acta 2002;392-393:357-69. doi:10.1016/S0040-6031(02)00121-1.

[18] Maton C, De Vos N, Stevens CV. Ionic liquid thermal stabilities: Decomposition mechanisms and analysis tools. Chem. Soc. Rev. 2013;42:5963-77. doi:10.1039/C3CS60071H.

[19] Meine N, Benedito F, Rinaldi R. Thermal stability of ionic liquids assessed by potentiometric titration. Green Chem. 2010;12:1711-14. doi:10.1039/C0GC00091D.

[20] Ngo HL, LeCompte K, Hargens L, McEwen AB. Thermal properties of imidazolium ionic liquids. Thermochim. Acta 2000;357-358:97-102. doi:10.1016/S0040-6031(00)00373-7.

[21] Paulechka YU, Zaitsau DH, Kabo GJ, Strechan AA. Vapour pressure and thermal stability of ionic liquid 1-butyl-3- methylimidazolium Bis(trifluoromethylsulfonyl)amide. Thermochim. Acta 2005;439:158-60. doi:10.1016/j.tca.2005.08.035.

[22] Kosmulski M, Gustafsson J, Rosenholm JB. Thermal stability of low temperature ionic liquids revisited. Thermochim. Acta 2004;412:47-53. doi:10.1016/j.tca.2003.08.022. 
[23] Seeberger A, Andresen AK, Jess A. Prediction of long-term stability of ionic liquids at elevated temperatures by means of non-isothermal thermogravimetrical analysis. Phys. Chem. Chem. Phys. 2009;11:9375-81. doi: 10.1039/B909624H.

[24] Wooster TJ, Johanson KM, Fraser KJ, MacFarlane DR, Scott JL. Thermal degradation of cyano containing ionic liquids. Green Chem. 2006; 8:691-6. doi:10.1039/B606395K.

[25] Del Sesto RE, McCleskey TM, Macomber C, Ott KC, Koppisch AT, Baker GA, et al. Limited thermal stability of imidazolium and pyrrolidinium ionic liquids. Thermochim. Acta 2009;491:11820. doi:10.1016/j.tca.2009.02.023.

[26] Hernández Battez A, Bartolomé M, Blanco D, Viesca JL, Fernández-González A, González R. Phosphonium cation-based ionic liquids as neat lubricants: Physicochemical and tribological performance. Tribol. Int. 2016;95:118-31. doi:10.1016/j.triboint.2015.11.015.

[27] Fox DM, Gilman JW, De Long HC, Trulove PC. TGA decomposition kinetics of 1-butyl-2,3dimethylimidazolium tetrafluoroborate and the thermal effects of contaminants. J. Chem. Thermodyn. 2005;37:900-5. doi:10.1016/j.jct.2005.04.020.

[28] Bredin A, Larcher A V, Mullins BJ. Thermogravimetric analysis of carbon black and engine sootTowards a more robust oil analysis method. Tribol. Int. 2011;44:1642-50. doi:10.1016/j.triboint.2011.06.002.

[29] Ye C, Liu W, Chen Y, Yu L. Room-temperature ionic liquids: a novel versatile lubricant. Chem Commun (Camb) 2001:2244-5. doi:10.1039/B106935G.

[30] Minami I. Ionic liquids in tribology. Molecules 2009;14:2286-305. doi:10.3390/molecules14062286.

[31] Qu J, Blau PJ, Dai S, Luo H, Meyer HM. Ionic Liquids as Novel Lubricants and Additives for Diesel Engine Applications. Tribol Lett 2009;35:181-9. doi:10.1007/s11249-009-9447-1.

[32] Palacio M, Bhushan B. A review of ionic liquids for green molecular lubrication in nanotechnology. Tribol Lett 2010;40:247-68. doi:10.1007/s11249-010-9671-8.

[33] Battez AH, González R, Viesca JL, Blanco D, Asedegbega E, Osorio A. Tribological behaviour of two imidazolium ionic liquids as lubricant additives for steel/steel contacts. Wear 2009;266:1224-8. http://dx.doi.org/10.1016/j. wear.2009.03.043.

[34] Liu W, Ye C, Gong Q, Wang H, Wang P. Tribological performance of room- temperature ionic liquids as lubricant. Tribol Lett 2002;13:81-5. http://dx.doi. org/10.1023/A:1020148514877. 
[35] Jiménez AE, Bermúdez MD. Imidazolium ionic liquids as additives of the synthetic ester propylene glycol dioleate in aluminium-steel lubrication.Wear 2008;265:787-98. http://dx.doi.org/10.1016/j.wear.2008.01.009.

[36] Freire MG, Neves CMSS, Marrucho IM, Coutinho JAP, Fernandes AM. Hydro- lysis of tetrafluoroborate and hexafluorophosphate counter ions in imidazo- lium-based ionic liquids. J Phys Chem A 2009;114:3744-9. http://dx.doi.org/ 10.1021/jp903292n.

[37] Viesca J-L, Anand M, Blanco D, Fernández-González A, García A, Hadfield M. Tribological behaviour of PVD coatings lubricated with a FAP? anion-based ionic liquid used as an additive. Lubricants 2016;4:8. http://dx.doi.org/ 10.3390/lubricants4010008.

[38] Viesca JL, García A, Hernández Battez A, González R, Monge R, Fernández- González A, Hadfield M. FAP- anion ionic liquids used in the lubrication of a steel-steel contact. Tribol Lett 2013;52:4317. http://dx.doi.org/10.1007/ s11249-013-0226-7.

[39] Hernández Battez A, González R, Viesca JL, Fernández-González A, Hadfield M. Lubrication of PVD coatings with ethyl-dimethyl-2-methoxyethylammonium tris(pentafluoroethyl)trifluorophosphate. Tribol Int 2013;58:71-8. http://dx. doi.org/10.1016/j.triboint.2012.10.001.

[40] González R, Hernández Battez A, Blanco D, Viesca JL, Fernández-González A. Lubrication of TiN, CrN and DLC PVD coatings with 1-butyl-1- methylpyrro- lidinium tris(pentafluoroethyl)trifluorophosphate. Tribol 2010;40:269-77. http://dx.doi.org/10.1007/s11249-010-9674-5.

[41] González R, Battez AH, Viesca JL, Higuera-Garrido A, Fernández-González A. Lubrication of DLC coatings with two tris(pentafluoroethyl)trifluorophosphate anion-based ionic liquids. Tribol Trans 2013;56:887-95. http://dx.doi.org/ 10.1080/10402004.2013.810319.

[42] Blanco D, González R, Hernández Battez A, Viesca JL, Fernández-Gonzlez A. Use of ethyldimethyl-2-methoxyethylammonium tris(pentafluoroethyl) tri- fluorophosphate as base oil additive in the lubrication of TiN PVD coating. Tribol Int 2011;44:645-50. http://dx.doi.org/10.1016/j.triboint.2011.01.004.

[43] Minami I, Kita M, Kubo T, Nanao H, Mori S. The tribological properties of ionic liquids composed of trifluorotris(pentafluoroethyl) phosphate as a hydro- phobic anion. Tribol Lett 2008;30:215-23. http://dx.doi.org/10.1007/ s11249-008-9329-y. 
[44] García A, González R, Hernández Battez A, Viesca JL, Monge R, Fernández- González A, Hadfield M. Ionic liquids as a neat lubricant applied to steel-steel contacts. Tribol Int 2014;72:42-50. http://dx.doi.org/10.1016/j. triboint.2013.12.007.

[45] Blanco D, Battez AH, Viesca JL, González R, Fernández-González A. Lubrication of CrN coating with ethyl-dimethyl-2-methoxyethylammonium tris(penta- fluoroethyl)trifluorophosphate ionic liquid as additive to PAO 6. Tribol Lett 2011;41:295-302.

[46] Somers AE, Biddulph SM, Howlett PC, Sun J, MacFarlane DR, Forsyth M. A comparison of phosphorus and fluorine containing IL lubricants for steel on aluminium. Phys Chem Chem Phys 2012;14:8224. http://dx.doi.org/10.1039/ c2cp40736a.

[47] Kheireddin BA, Lu W, Chen IC, Akbulut M. Inorganic nanoparticle-based ionic liquid lubricants. Wear 2013;303:185-90. http://dx.doi.org/10.1016/j. wear.2013.03.004.

[48] Somers AE, Howlett PC, Sun J, MacFarlane DR, Forsyth M. Transition in wear performance for ionic liquid lubricants under increasing load. Tribol Lett 2010;40:279-84. http://dx.doi.org/10.1007/s11249-010-9695-0.

[49] Murakami T, Kaneda K, Nakano M, Korenaga A, Mano H, Sasaki S. Tribological properties of Fe7Mo6-based alloy under two ionic liquid lubrications. Tribol Int 2008;41:1083-9. http://dx.doi.org/10.1016/j.triboint.2008.02.017.

[50] Bandeira P, Monteiro J, Baptista AM, Magalhães FD. Tribological performance of PTFE-based coating modified with microencapsulated [HMIM][NTf2] ionic liquid. Tribol Lett 2015:59. http://dx.doi.org/10.1007/s11249-015-0545-y.

[51] Gabler C, Dörr N, Allmaier G. Influence of cationic moieties on the tribolayer constitution shown for bis(trifluoromethylsulfonyl)imide based ionic liquids studied by X-ray photoelectron spectroscopy. Tribol Int 2014;80:90-7. http: //dx.doi.org/10.1016/j.triboint.2014.06.018.

[52] Pisarova L, Gabler C, Dörr N, Pittenauer E, Allmaier G. Thermo-oxidative sta- bility and corrosion properties of ammonium based ionic liquids. Tribol Int 2012;46:73-83. http://dx.doi.org/10.1016/j.triboint.2011.03.014.

[53] Monge R, González R, Hernández Battez A, Fernández-González A, Viesca JL, García A, Hadfield M. Ionic liquids as an additive in fully formulated wind turbine gearbox oils. Wear 2015;328329:50-63. http://dx.doi.org/10.1016/j. wear.2015.01.041. 
[54] Somers A, Howlett P, MacFarlane D, Forsyth M. A Review of Ionic Liquid Lubricants. Lubricants 2013;1:3-21. doi:10.3390/lubricants1010003.

[55] Minami I, Inada T, Sasaki R, Nanao H. Tribo-chemistry of phosphonium-derived ionic liquids. Tribol. Lett. 2010;40:225-35. doi:10.1007/s11249-010-9626-0.

[56] Otero I, López ER, Reichelt M, Villanueva M, Salgado J, Fernández J. Ionic liquids based on phosphonium cations as neat lubricants or lubricant additives for a steel/steel contact. ACS Appl. Mater. Interfaces 2014;6:13115-28. doi:10.1021/am502980m.

[57] Barnhill WC, Qu J, Luo H, Meyer HM, Ma C, Chi M, et al. Phosphonium-organophosphate ionic liquids as lubricant additives: Effects of cation structure on physicochemical and tribological characteristics. ACS Appl. Mater. Interfaces 2014;6:22585-93. doi:dx.doi.org/10.1021/am506702u.

[58] Somers AE, Khemchandani B, Howlett PC, Sun J, Macfarlane DR, Forsyth M. Ionic liquids as antiwear additives in base oils: Influence of structure on miscibility and antiwear performance for steel on aluminum. ACS Appl. Mater. Interfaces 2013;5:11544-53. doi:10.1021/am4037614.

[59] González R, Bartolomé M, Blanco D, Viesca JL, Fernández-González A, Battez AH. Effectiveness of phosphonium cation-based ionic liquids as lubricant additive. Tribol Int 2016;98:82-93. doi:10.1016/j.triboint.2016.02.016.

[60] Qu J, Bansal DG, Yu B, Howe JY, Luo H, Dai S, et al. Antiwear performance and mechanism of an oil-miscible ionic liquid as a lubricant additive. ACS Appl Mater Interfaces 2012;4:997-1002. doi:10.1021/am201646k.

[61] Yu B, Bansal DG, Qu J, Sun X, Luo H, Dai S, et al. Oil-miscible and non-corrosive phosphoniumbased ionic liquids as candidate lubricant additives. Wear 2012;289:58-64. doi:10.1016/j.wear.2012.04.015.

[62] Qu J, Luo H, Chi M, Ma C, Blau PJ, Dai S, et al. Comparison of an oil-miscible ionic liquid and ZDDP as a lubricant anti-wear additive. Tribol Int 2014;71:88-97. doi:10.1016/j.triboint.2013.11.010.

[63] Rui L, Meirong Y, Xiaopeng X. Thermal stability and thermal decomposition kinetics of 1-butyl-3methylimidazolium dicyanamide. Chin. J. Chem. Eng. 2010;18:736-41. doi:10.1016/S10049541(09)60122-1. 
[64] Heym F, Etzold BJM, Kern C, Jess A. An improved method to measure the rate of vaporisation and thermal decomposition of high boiling organic and ionic liquids by thermogravimetrical analysis. Phys Chem Chem Phys 2010;12:12089-100. doi:10.1039/C0CP00097C.

[65] Heym F, Etzold BJM, Kern C, Jess A. Analysis of evaporation and thermal decomposition of ionic liquids by thermogravimetrical analysis at ambient pressure and high vacuum. Green Chem 2011;13:1453-66. doi:10.1039/C0GC00876A.

[66] Ramajo-Escalera B, Espina A, García JR, Sosa-Arnao JH, Nebra SA. Model-free kinetics applied to sugarcane bagasse combustion. Thermochim. Acta 2006;448:111-6. doi:10.1016/j.tca.2006.07.001.

[67] Vyazovkin SV, Lennikovich AI. On the methods of solving the inverse problem of solid-phase reaction kinetics. J. Thermal. Anal. 1989;35:2169-88. doi: 10.1007/BF01911882.

[68] Zhang K, Hong J, Cao G, Zhan D, Tao Y, Cong C. The kinetics of thermal dehydration of copper(II) acetate monohydrate in air. Thermochim. Acta 2005;437:145-9. doi:10.1016/j.tca.2005.06.038.

[69] Gurman JL, Baier L, Levin BC. Polystyrenes: A review of the literature on the products of thermal decomposition and toxicity. Fire and Materials 1987;11:109-30. doi:10.1002/fam.810110302.

[70] Fernandes GJT, Araujo AS, Fernandes VJ, Novak C. Model-free kinetics applied to regeneration of coked alumina. J. Therm. Anal. Calorim. 2004;75:687-92. doi:10.1023/B:JTAN.0000027163.44593.4a.

[71] Mohanraj GT, Vikram T, Shanmugharaj AM, Khastgir D, Chaki TK. Kinetics of thermal degradation of conductive styrene butadiene rubber carbon black composites. J. Mat. Sci. 2006;41:4777-89. doi: 10.1007/s10853-006-0065-0.

[72] Vyazovkin S, Sbirrazzuoli N. Confidence intervals for the activation energy estimated by few experiments. Anal. Chim. Acta 1997;355:175-80. doi:10.1016/S0003-2670(97)00505-9.

[73] Akahira T, Sunose T. Joint convention of four electrical institutes. Res. Rep. Chiba Inst. Technol. 1971;16: 22-31.

[74] Baumgarten HE, Setterquist RA. Pyrolysis of Alkyl Phosphates. J Am Chem Soc 1957;79:2605-8. doi:10.1021/ja01567a066.

[75] Vyazovkin S, Wight CA. Kinetics in solids. Annu. Rev. Phys. Chem. 1997;48:125-49. doi: 10.1146/annurev.physchem.48.1.125. 
[76] Xue Z, Zhang Y, Zhou XQ, Cao Y, Mu T. Thermal stabilities and decomposition mechanism of amino- and hydroxyl-functionalized ionic liquids. Thermochim. Acta 2014;578:59-67. doi:10.1016/j.tca.2013.12.005.

[77] Crosthwaite JM, Muldoon MJ, Dixon JK, Anderson JL, Brennecke JF. Phase transition and decomposition temperatures, heat capacities and viscosities of pyridinium ionic liquids. J. Chem. Thermodyn. 2005;37:559-68. doi:10.1016/j.jct.2005.03.013.

[78] Strauss SH. The search for larger and more weakly coordinating anions. Chem. Rev. 1993;93:92742. doi:10.1021/cr00019a005.

[79] Hao Y, Peng J, Hu S, Li J, Zhai M. Thermal decomposition of allyl-imidazolium-based ionic liquid studied by TGA-MS analysis and DFT calculations. Thermochim Acta 2010;501:78-83. doi:10.1016/j.tca.2010.01.013.

[80] Kroon MC, Buijs W, Peters CJ, Witkamp GJ. Quantum chemical aided prediction of the thermal decomposition mechanisms and temperatures of ionic liquids. Thermochim Acta 2007;465:40-7. doi:10.1016/j.tca.2007.09.003.

[81] Chambreau SD, Schenk AC, Sheppard AJ, Yandek GR, Vaghjiani GL, Maciejewski J, et al. Thermal decomposition mechanisms of alkylimidazolium ionic liquids with cyano-functionalized anions. J Phys Chem A 2014;118:11119-32. doi:10.1021/jp5095855.

[82] Keating MY, Gao F, Ramsey JB. TGA-MS study of the decomposition of phosphorus- containing ionic liquids trihexyl(tetradecyl)phosphonium decanoate and trihexyltetradecylphosphonium bis[(trifluoromethyl)sulfonyl] amide, Journal of Thermal Analysis and Calorimetry 106 (2011) 207211.

[83] Götz M, Reimert R, Bajohr S, Schnetzer H, Wimberg J, Schubert TJS. Long-term thermal stability of selected ionic liquids in nitrogen and hydrogen atmosphere. Thermochim. Acta 2015;600:82-8. doi:10.1016/j.tca.2014.11.005.

[84] Menczel JD, Prime RB. Thermal Analysis of Polymers: Fundamentals and Applications. Wiley, 2009.

[85] Vyazovkin S, Burnham AK, Criado JM, Pérez-Maqueda LA, Popescu C, Sbirrazzuoli N. ICTAC Kinetics Committee recommendations for performing kinetic computations on thermal analysis data. Thermochim Acta 2011;520:1-19. doi:10.1016/j.tca.2011.03.034. 
[86] Vyazovkin S, Chrissafis K, Di Lorenzo ML, Koga N, Pijolat M, Roduit B, Sbirrazzuoli N, Suñol JJ. ICTAC Kinetics Committee recommendations for collecting experimental thermal analysis data for kinetic computations. Thermochim Acta 2014;590:1-23. doi:10.1016/j.tca.2014.05.036.

[87] Kok MV, Topa E. Thermal characterization and model-free kinetics of biodiesel sample. J Therm Anal Calorim 2015;122:955-61. doi:10.1007/s10973-015-4814-7.

[88] Bourbigot S, Gilman JW, Wilkie CA. Kinetic analysis of the thermal degradation of polystyrenemontmorillonite nanocomposite. Polym. Degrad. Stab. 2004;84:483-92. doi:10.1016/j.polymdegradstab.2004.01.006.

[89] Wanjun T, Yuwen L, Xil Y, Zhiyong W, Cunxin W. Approximate formulae for calculation of the integral $\int_{0}^{T} T^{m} e^{-E_{\alpha} / R T} d T$. J Therm Anal Calorim 2005;81:347-9. doi:10.1007/s10973-005-0790-7. 